\title{
Post-operative immune suppression is reversible with interferon gamma and independent of IL- 6 pathways
}

ER Longbottom ${ }^{1,2^{*}}$, HDT Torrance ${ }^{1,2}$, HC Owen ${ }^{1}$, CJ Hinds ${ }^{1,2}$, RM Pearse ${ }^{1,2}$, MJ O$^{\prime}$ Dwyer $^{1,2}$

From ESICM LIVES 2015

Berlin, Germany. 3-7 October 2015

\section{Introduction}

The post-operative period is characterised by increased IL-6 production and clinical features of immune suppression. In vitro anti-inflammatory actions of IL-6 are mediated through suppression of interferon gamma (IFN $\gamma$ ) [1]. The clinical significance of IL-6 in mediating post-operative immune suppression remains unclear.

\section{Objectives}

To evaluate the role of IL- 6 pathways in post-operative immune suppression and the reversibility of this phenomenon.

\section{Methods}

Patients over 45 years old undergoing elective surgery involving the gastrointestinal tract and requiring at least
$1 \mathrm{~A}$

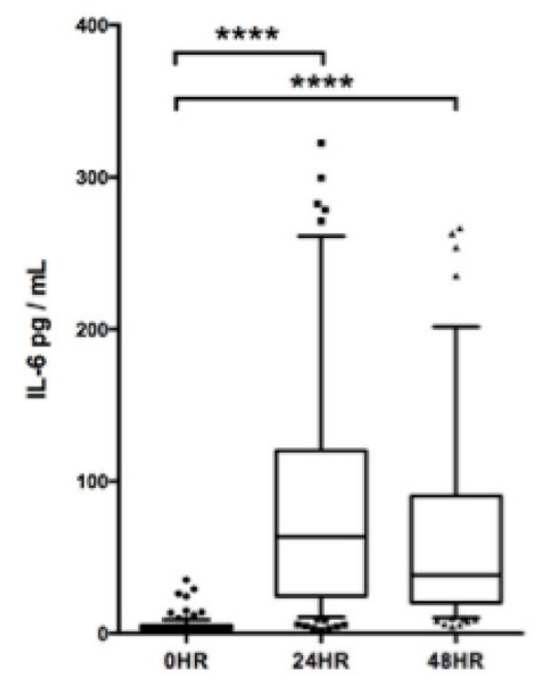

1B

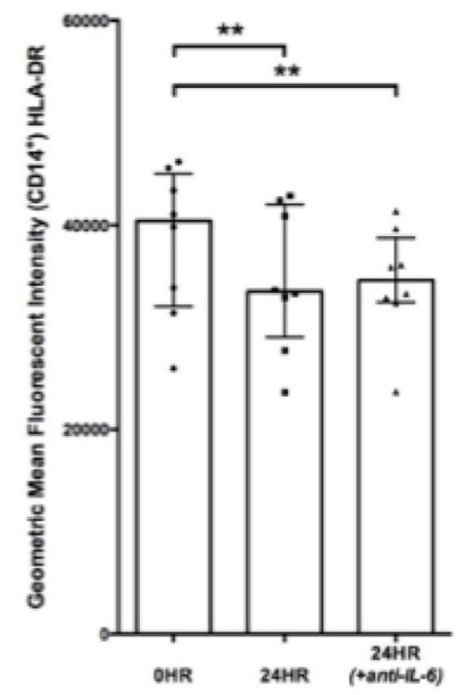

Figure 1 
Table 1 Characteristics of patients developing infections and those remaining infection free following scheduled abdominal surgery.

\begin{tabular}{lccc}
\hline & Infection & Infection free & $\boldsymbol{P}$ Value \\
& $\boldsymbol{N}=\mathbf{4 4}$ (37\%) & $\boldsymbol{N}=\mathbf{7 5}$ (63\%) & 0.19 \\
Age (years) & $66(59-75)$ & $64(56-71)$ & $47(63)$ \\
Male sex (\%) & $27(61)$ & $12(16)$ & 0.89 \\
Diabetes (\%) & $8(18)$ & $14(19)$ & 0.76 \\
Current smokers (\%) & $10(23)$ & $53(71)$ & 0.60 \\
Cancer diagnosis (\%) & $24(55)$ & $10(14)$ & 0.07 \\
Preoperative Immunosuppression (\%) & $6(14)$ & $195(142-295)$ & 0.99 \\
Duration of operation (minutes) & $243(176-312)$ & 0.06 \\
\hline
\end{tabular}

Data are described as median with interquartile range with percentages in parenthesis

an overnight hospital stay were recruited. The primary outcome was hospital-acquired infection. IL-6 and IFN $\gamma$ levels were assayed using ELISA preoperatively and at 24 and 48 hours. Pooled healthy control peripheral blood mononuclear cells (PBMCs) were cultured in perioperative serum and CD14 ${ }^{+}$HLA-DR (mHLA-DR) geometric mean florescent intensity (MFI) measured in the presence and absence of interferon gamma (IFN $\gamma$ ) and IL-6 neutralising antibody. Data were analysed with non-parametric statistics.

\section{Results}

119 patients were recruited and $44(37 \%)$ developed a post-operative infection a median of 9 (IQR 5-11) days postoperatively (Figure 1). IL-6 levels increased from baseline to 24 hours postoperatively $(P<0.0001$, Figure $1 \mathrm{~A})$ but were then unchanged between 24 and 48 hours $(P=$ 0.06 , Figure 1B). Postoperative IL-6 levels correlated with the duration of the procedure $(P=0.009)$. Higher preoperative IL-6 levels were observed in patients with cancer $(P=0.02)$. IL-6 levels at $24(P=0.0002)$ and 48 hours $(P=$ $0.003)$ were associated with the later occurrence of infectious complications. This pattern remained similar after adjustment for baseline characteristics. Healthy donor PBMCs incubated with postoperative serum downregulated mHLA-DR MFI when compared with serum from baseline $(\mathrm{n}=8, \mathrm{p}=0.008)$. Culturing in the presence of IFN $\gamma 250 I U(n=4)$ prevented this decrease whereas culturing in the presence of IL-6 neutralising antibody $15 \mathrm{ng} / \mathrm{ml}(\mathrm{n}=8)$ did not.

\section{Conclusions}

IL-6 levels increase following major surgery and are associated with an increased susceptibility to post-operative infections. Serum obtained from post-operative patients induces an immunosuppressive response through an IL-6 independent pathways which is reversible with IFN $\gamma$ treatment.

\section{Grant Acknowledgment}

The National Institute of Academic Anaesthesia (NIAA)

\section{Authors' details}

'Barts \& the London School of Medicine, QMUL, William Harvey Research Institute, London, United Kingdom. ${ }^{2}$ Barts Health NHS Trust, Adult Critical Care Unit, London, United Kingdom.

Published: 1 October 2015

Reference

1. Diehl $\mathrm{S}$, et al: The two faces of IL-6 on Th1/Th2 differentiation. Mol Immunol 2002, 39(9):531-6, Dec.

doi:10.1186/2197-425X-3-S1-A820

Cite this article as: Longbottom et al: Post-operative immune suppression is reversible with interferon gamma and independent of IL6 pathways. Intensive Care Medicine Experimental 2015 3(Suppl 1):A820.

\section{Submit your manuscript to a SpringerOpen ${ }^{\circ}$ journal and benefit from: \\ - Convenient online submission \\ - Rigorous peer review \\ - Immediate publication on acceptance \\ - Open access: articles freely available online \\ - High visibility within the field \\ - Retaining the copyright to your article}

Submit your next manuscript at $\boldsymbol{~ s p r i n g e r o p e n . c o m ~}$ 